\title{
Robert Jenson's ecumenical vision based on his Trinitarian thought
}

\begin{abstract}
The American Lutheran theologian, Robert Jenson, is well known as an ecumenical theologian. He is also well known as a significant and prolific writer of Trinitarian theology during the last forty years. These two themes, Ecumenism and Trinity, are very closely interconnected in Jenson's life and work. We can say that his Trinitarian theology has been his leitmotiv and inspiration for his life-long ecumenical engagement, and vice versa, that his ecumenical vision and dedication has influenced and motivated his Trinitarian theology in many ways. In this paper I will explore the ecumenical perspectives and proposals Jenson has made as logical implications of his Trinitarian theology. I will argue that his understanding of the relationship between the Trinity and time helped to form his ecumenical vision and contributed to some of his ecumenical proposals. This will give an indication of how Jenson is searching for a theology of the one church of the future.
\end{abstract}

\section{INTRODUCTION}

Robert Jenson is not only well known as a Trinitarian theologian, ${ }^{1}$ but also as an ecumenical theologian. ${ }^{2}$ In this regard his books and involvement with the ecumenical movement testify about his life-long commitment to ecumenism. His more ecumenical focused books were mostly written later in his life and include: Visible Words: The Interpretation and Practice of the Christian Sacraments (1978), Unbaptized God: The Basic flaw in Ecumenical Theology (1992), The Catholicity of the Reformation (1996, with Braaten), Jews and Christians (2003, with Braaten), In One Body through the Cross. The Princeton Proposal for Christian Unity (2003, with Braaten), and The Ecumenical Future (2004, with Braaten). ${ }^{3}$

1 See my previous article in this regard: "Trinity, Time and Ecumenism in Robert Jenson's theology."

2 Colin Gunton was the editor of this festschrift about Jenson and the strong link between Trinity and ecumenism in Jenson's work is also here emphasised by Gunton: "The chapters in this Festschrift [Trinity, Time, and Church (2000)] offer eloquent tribute to the significance of this remarkable achievement of writing on dogmatics for the whole church in an ecumenical key" (Braaten 2000:8).

3 The Princeton Proposal (2003) is a remarkable book in the sense that it was written by a group of sixteen theologians from different church traditions. It gives an overview of the current ecumenical state and also investigates future possibilities for ecumenism. The proposals seek to steer contemporary efforts at church unity away from social and political agendas to what they consider to be the main goal of the modern ecumenical movement, namely the visible unity of Christians worldwide, of all those who are reconciled "in one body through the cross" (as the title says). The following quote from the book says something of this attempt: "We all suffer from the wounds of division. These wounds extend into our theologies, our institutional structures, and our very sense of what makes the church life-giving. Significant aspects of our traditions must be rethought if they are truly to witness to the one apostolic faith rather than to our divisions. Therefore we must examine our collective consciences and repent of actions, habits, and sentiments that glory in division" (Braaten \& Jenson 2003:57-58).

The background papers of the Princeton Proposal, was published as The Ecumenical Future (2004). 
Jenson's ecumenical commitment is also visible in his involvement with ecumenical centres and journals. In 1990 Jenson and Braaten founded the Centre for Catholic and Evangelical Theology, which were specifically ecumenical in its focus. In 1992 Jenson and Braaten started a new journal for this Centre, Pro Ecclesia, ${ }^{4}$ of which Jenson later said: "It quickly became a major forum for churchly theology from all wings of the ecumene. And we editors increasingly internalized the journal's stated goals" (Jenson 2007:52).

Jenson's ecumenical involvement also includes lively participation in inter-denominational discussions. In 1968 when Jenson went back to America from England, ${ }^{5}$ he was appointed to the first round of US Episcopal/Lutheran dialogue and helped to formulate important ecumenical perspectives regarding the episcopé. ${ }^{6}$ Later on in his life he was also involved with the Catholic/Lutheran discussion and was appointed permanent adviser to the third round of the international dialogue. There he worked, with other Lutheran and Catholic theologians, for more than ten years on the relation between justification and ecclesiology. Of this involvement he said: "I thought of ecumenical dialogue as the attempt together to think new thoughts, that might transcend otherwise intractable divisions... Nevertheless, those were exciting years, in the course of which I became more and more committed to the ecumenical movement..." (Jenson 2007:52). Furthermore, in 1988 he spent a year at the Centre d'Étude Oecumenique at Strasbourg where he did research about the ecumenical dialogues and blockades of the time. ${ }^{7}$

Gabriel Fackre wrote on the cover page of this book: "The future of ecumenism depends on the resolution of the issues discussed in this welcome work. Major figures in the recent history of the ecumenical movement, along with younger heirs, give a fresh slant on its problems and possibilities in this collection of background papers to the important Princeton Proposal. Read it and weep ... or hope." Jenson says in the preface of the book: "Ecumenism is a function of authentic Christian faith; the ecumenical quest for church unity is based on Jesus' high-priestly prayer in Chapter 17 of St. John's Gospel..." (Braaten \& Jenson 2004: viii).

4 The purpose of Pro Ecclesia was ecumenical from the beginning. In the words of Jenson: "For many years the chief organ of high church Lutherans in America was a journal entitled Una Sancta. Indeed, in some loose sense this journal was the spiritual predecessor of Pro Ecclesia, the journal of the Centre for Catholic and Evangelical Theology. The great difference is that Una Sancta was a Lutheran journal, whereas Pro Ecclesia is an ecumenical journal, supported by theologians of many traditions" (Braaten \& Jenson 1996: ix).

5 He lectured at Oxford University as the "Lutheran World Federation Lecturer in Theology" during 19661968 and 1972-1973. Of this time Jenson said: "We found ourselves in the heart of Anglicanism, then still possessing its seductive combination of rabies-free theology and the West's most faithful liturgical order, the Book of Common Prayer. And I found myself cast as a one-man ecumenical movement" (Jenson 2007:51).

6 I will discuss Jenson's proposals about the episcopé in more detail later in the paper, but it is interesting to note here what Jenson himself said about the US Episcopal/Lutheran dialogue about the episcopacy. Jenson wrote: "The group quickly decided that if each party could just accept where the other located its doctrine, the Lutherans in documents and the Episcopalians in prayers, there was little that divided us but 'historic episcopacy'. Thereupon Reginald Fuller and I worked out the distinction between necessary episcopé, oversight, and the possibly variable historical ordering of that function. For compelling reasons, we said, the Anglicans retained the historical order in the $16^{\text {th }}$ century, and for equally compelling reasons most Lutherans let it go. Each side could affirm the other, and then consider what to do now. The distinction is now standard: ours seems to have been in 1971 the first official dialogue to propose it" (Jenson 2007:52).

7 Jenson's book, Unbaptized God: The basic flaw in Ecumenical Theology (1992), followed from this researched. About this book he later wrote: "At the time, it was thought that a "basic difference" between Catholicism and the Reformation might account for the frustrations of ecumenical dialogue. In Unbaptized God: The basic flaw in Ecumenical Theology we proposed instead that the problems stemmed from a "basic agreement" in an inadequately Trinitarian intuition of God." The link between Trinity and Ecumenism is thus here already very clear in Jenson's thought and it will remain so throughout his 
For the last seven years before Jenson retired, he worked as the Senior Scholar for Research at Princeton at the Centre of Theological Inquiry, which Jenson described as the centre of a worldwide ecumenical network. ${ }^{8}$

Jenson's Trinitarian theology has been his leitmotiv and inspiration for his life-long ecumenical engagement, and vice versa, his ecumenical vision and dedication has influenced and motivated his Trinitarian theology in many ways. ${ }^{9}$ For example, although Jenson's Systematic Theology $(1997,1999)^{10}$ is mainly a dogmatic work, the second volume is an exposition of his ecumenical thoughts based on his Trinitarian theology of the first volume. It is this link between his Trinitarian thought and his ecumenical vision that I will explore in this article. In my previous article I focused on Jenson's Trinitarian theology and in this one I will focus on his ecumenical vision and proposals. In short the argument will show that Jenson's Trinitarian theology - and specifically his understanding of God and time - opens up some new possibilities for his specific ecumenical ideas and proposals.

\section{JENSON'S ECUMENICAL VISION AND PROPOSALS}

In developing his strong ecclesiology Jenson proposes several important ecumenical perspectives. In his and Braaten's book, The Catholicity of the Reformation (1996), ${ }^{11}$ Jenson's preference for the term catholicity - instead of ecumenical - becomes clear. ${ }^{12}$ Although these terms broadly include the same field of reference, the term catholicity represents a stronger faith and doctrinal perspective than the twentieth century's Protestant perspective often associated with the term ecumenism. In their book, Catholicity, Jenson explains that the Reformers aimed to reform a church that lived in continuity with the Church the Creed calls "one, holy, catholic and apostolic", but Protestant churches have not always understood themselves as catholic. Catholic though, means "whole" or "total" (it derives from the Greek kata (according to) and holos (the whole))

theological career. In Unbaptized God Jenson argues that Christian theology took over a Hellenistic divinity without 'baptizing' it. With that he means that God's impassibility and timelessness (as part of the Greek metaphysics) was not overcome in Christian theology and that it is exactly this problem that lead in a great extent to later ecumenical dividedness. His theology is therefore a reaction and correction to this timelessness of God, always with an ecumenical goal.

8 Jenson says that it was at the Center of Theological Inquiry where he came in conversation with a range of Christians and Jews (his book Jews and Christians. People of God (2003) was written in this time) and that he "learned to appreciate the Presbyterians across the street" (Jenson 2007:53). Jenson's wide scope of ecumenism is also apparent when he says: "It is an abiding conviction: theological discourse among Jews and Christians is not inter-religious dialogue" (Jenson 2007:53).

9 Jenson is very clear about this link between ecumenism and Trinitarian theology and how the one is done with the aim of the other and vice versa: “... it is a great blessing specifically to theology that we need not wait for the church to be undivided to do theology for and even of the undivided church. For theology is itself a form of the waiting we must practice. The present work [his Systematic Theology] is deliberately done in such anticipation of the one church, and this will be throughout apparent, in its use of authorities and its modes of argument" (ST1:viii), and "...the doctrine of Trinity is ever more decisively the key in all my thinking" (Jenson 2007:54).

10 Systematic Theology, Volume 1: The Triune God (1997) and Systematic Theology, Volume 2: The Works of God (1999). Hereafter referred to as ST1 and ST2. Braaten says these books are undoubtly the crowning fulfilment of Jenson's career and 'when he [Jenson] is asked, 'How long did it take you to write it?' his answer is, "The last forty years." (Braaten 2000:8).

11 Jenson and Braaten are the editors of this book which consists out of essays of different authors who tries to demonstrate the catholicity of the Reformers and who stresses the importance of recovering the church's catholic tradition for today.

12 In example, the centre Jenson and Braaten founded in 1990 was called the Centre for Catholic and Evangelical Theology. 
and the catholicity of the church is thus its completed integrity and comprehensiveness, its wholeness. According to Jenson the "church is catholic when the living Christ is present" (Jenson 1996:vii). He says the catholicity of the church includes many things: the Scripture, apostolic tradition, sacraments, ecumenical creeds, worship, and the ministry. I will further investigate some of these aspects, namely the Eucharist and the prayers of the departed saints, as examples of Jenson's ecumenical proposals as he is in search of the full catholicity of the church. ${ }^{13}$ The first aspect on which I will focus is the sacraments, especially the Eucharist.

\section{The Eucharist}

The incorporation into the risen Christ's own body is according to Jenson enacted in the church's celebration of Eucharist and not only through the community of the church. In his discussion of Paul's first letter to the Corinthians, Jenson says we may ask which body of the Lord Paul intends: is it the bread and cup or is it the congregation? Jenson answers: "It is plain: Paul intends both at once, in dynamic identity" (Jenson 1996:5). Jenson thus agrees with the patristic interpretation of Eucharist as the commune (koinonein) with Christ, and the share in his body and his deity, as well as commune as the uniting with one another. With the patristic father, John of Damascus, he says "for because we all eat one loaf we become one body and one blood of Christ and members of one another; we may be said to be embodied with Christ (sussomoi tou christou)" (Jenson 1996:6). ${ }^{14}$ Jenson (ST2:212) says it has become a standard item of ecumenical consensus that churchly and Eucharistic communion is one, in that both are communion in the body of Christ. ${ }^{15}$ Jenson uses the term communion-ecclesiology to express this unique communion the church has and says that at Eucharist we receive one another with Christ and Christ with one another; "we are precisely 'co-embodiments' of Christ" (ST2:222). This communion-ecclesiology is a fully integral part of Jenson's Trinitarian understanding of the church's communion in the Trinity. ${ }^{16}$ For Jenson the church is already the totus Christus, but still exists in anticipation and what she anticipates is the full inclusion in the triune communion.

With the Eucharist established as central for our understanding of the church as communionecclesiology, ${ }^{17}$ Jenson acknowledges an important insistence by the Orthodoxy on the agency of the Spirit with respect to Eucharist communion - one that he thinks Protestants and Roman Catholics should incorporate. Jenson says the "old East-West controversy about the 'moment of consecration' in the Eucharistic liturgy... is in abeyance and we may hope will remain so. But Orthodoxy's insistence that there be the Epiclesis - as in many Protestant rites and in old Roman

13 Not all of Jenson's ecumenical proposals will be discussed here, but only some examples that will help us to see the clear link between his Trinitarian theology and his position on certain ecumenical issues. The scope of the article does not allow for a more comprehensive overview of all his ecumenical proposals. In the second volume of his Systematic Theology (1999) Jenson wrote chapters on the Polity of God, the Great Communion, the Office of Communion, the Mysteries of Communion, the Word and the Icons and on Anima Ecclesiastica, which are all ecumenically focused.

14 See also ST2:212 where Jenson makes the same point as part of his Systematic Theology.

15 Jenson refers here to the statement made by the Anglican-Orthodox Dialogue in Moscow (1976) which says: "The church celebrating the Eucharist becomes fully itself; that is, koinonia, fellowship communion. The church celebrates the Eucharist as the central act of its existence, in which the ecclesial community... receives its realization" (ST2:212).

16 He refers to the International Roman Catholic-Orthodox dialogue (1982) which formulation says: "the unity in love of plural persons... constitutes the... Trinitarian koinonia, which is communicated to humans in church" (ST2:222).

17 Jenson says: "The Eucharist promises: there is my body in the world, and you here eating and drinking commune in it. It promises: there is the actual historical church, and you are she. That the risen Christ is not merely 'spiritually' is itself a vital promise of the gospel, and the one made specifically by the bread and cup" (ST2:220). 
canon there lamentably has not been - has vital content" (ST2:227). The reason for this, Jenson says, is because the elements and the community gathered around them need to be freed from their merely historical reality if they are to be the body of Christ. It is precisely the Spirit's role to do that. This fits perfectly into Jenson's Trinitarian understanding of the church's communion: "As the church shares in the life of the triune identities, she shares in the relation of the Son and the Spirit to the Father" (ST2:227) and it also perfectly fits into his understanding of the Spirit (as the future in God) who is able to free him (and the church) from the past and present (from timelessness).

Another aspect of the Eucharist Jenson (ST2:215-220) investigates is the question if Christ's sacrifice can be repeated or supplemented. The problem is that if the Eucharist is in any sense a repetition of the sacrifice on the cross, it is supposed to supplement or add to the sacrifice on the cross. Jenson says Catholics agreed that at the time of the Reformation there were "'misunderstandings... in popular piety and theories of the mass in theology,' which indeed thought of the sacrifice of the mass in this way" (ST2:217). On the other hand the Reformation insisted that the mass is not a repetition and adds nothing to the sacrifice on the cross, and they denied altogether that the mass is a sacrifice of Christ. Jenson says that from the other side, Catholics were determined to maintain the hitherto universal recognition that the Eucharist is indeed a sacrifice and that Christ is its content. Jenson summarizes the problem and says $(S T 2: 218)$ that the Protestants thought they could preserve the uniqueness of the cross only by denying Eucharistic sacrifice, and Catholics thought they could affirm Eucharistic sacrifice only by positing some, however minimal, distinct identifications of Eucharistic sacrifice and of the one sacrifice on the cross. ${ }^{18}$

Jenson's ecumenical proposal here (ST2:258-259) is to make a constructive interpretation of the Eucharist as anamnetic ${ }^{19}$ sacrifice and it links up with the advanced ecumenical dialogues' call for a return to the notion of memorial or remembrance. Jenson refers to the AnglicanRoman Catholic International Commission's (1971) formulation of anamnesis or representation as "the making effective in the present of an event in the past" (ST2:258). This definition brings us back to temporal categories and it is here where Jenson's understanding of the Trinity and time becomes relevant again. With the words, "Do this for my remembrance," we may initially say that we celebrate Eucharist to remind someone of Jesus, but Jenson says it can also mean that we are to remind God. When someone remembers it is a present act and when it is God who remembers, his answer creates what it mentions. In this instance (of the Eucharist) the creative address is a response to a reminder; it creates the present tense of a past event. So is the sacrifice of the cross then repeated in the Eucharist? Jenson says (ST2:259) that with "remembrance" we moved from spatial to temporal categories, but space is only time's present tense. He says: "The relations between the place that God is and his heaven and our earth are founded in relations between the future and the present and the past. And it is these temporal relations that words open and maintain" (ST2:259). In the Eucharist, the words spoken are between God and the congregation and it is at once narrative of the past and promise of the eschatological future - the past is narrated just as the identity of the promised goal. So Jenson concludes that in this discourse a word that opens the future "comes to" the remembered past to do this and so makes the past alive. And "insofar as this converse visibly embodies itself in the

18 The differences on this issue had many liturgical consequences. On the one hand the Protestants have tried by liturgical truncations to make it impossible to experience the Eucharist as sacrifice (removing those parts that are plainly directed to God), and on the other hand "Roman Catholicism sometimes seemed bent on proving that it indeed commit "the abomination of the mass-sacrifice"" (ST2:218).

19 Jenson says we may generalize about this term and say: "anamnetic being is present reality created by a word of God that simultaneously evokes a past event and opens its future, to make it live in the present" $(S T 2: 258)$. 
objectivities of the church's life [i.e. Eucharist], these become signs with specific meaning... The narrated past is 're-presented' in them... But this presence is hidden in them, by their own visible appearance as... mere bread and cup..." (ST2:259-260). It is clear that Jenson's understanding of God's relation to time is crucial for this interpretation and that our inherited metaphysical view of God as timeless would be a problem to accept this position.

\section{The prayers of the departed saints}

Another interesting example of how Jenson's Trinitarian theology, and especially the Trinity's relation to time, has an influence on his ecumenical proposals can be found in his view of "the mystery of departed saints' prayer for us" (ST2:267-269) - an issue of ecumenical ecclesiology with hardly any consensus. Jenson affirms that Christians may certainly not in the proper sense pray to saints as that would be idolatry, but the question is if they may ask saints to pray for them, and do the saints in heaven hear and honour such requests? According to Jenson "Orthodox, Catholics, and a few Protestants invoke the saints, together and individually, and most Protestants do not; opposite practice at this point is one of the most obtrusive signs of churchly division" (ST2:268). Jenson agrees with the Apology of the Augsburg Confession of 1530 (the paradigmatic Protestant document in this matter) and says that there can be no rule of faith that believers must invoke the saints. Jenson understands this position as a Protestant ascesis that belongs to a general pattern of piety whose restraint and biblical criteria must commend it within the church. Jenson however, chose (as part of the whole tendency of his theology as he himself explains) to take a riskier route and test the invocation of the saints to the fact that only communion with Christ establishes the communion of the church. For Jenson then, "whatever communion the church on earth has with the church in heaven is also so founded. The saints are not our way to Christ; he is our way to them" (ST2:269). So Jenson concludes that our communion with departed saints is not fundamentally different from our communion with living saints. ${ }^{20}$ He says: "We may not ask Mary to bring us to Christ; because we are one with Christ we can address Mary" (ST2:269).

Jenson can make this conclusion because he sees the church as one communion through time - a community that cannot be broken by time's discontinuities because "it is founded in the eternal triune communion of God and is constituted in the Spirit who is the Power of eternal life. Thus the church is a single active communion of living saints and departed saints" (ST2:267). Here Jenson's temporal categories come into play again when he says saints are in heaven and heaven is the presence of the future Kingdom. As part of the Trinitarian-perichoretic dialectic he works with, he can say that "to speak to the saints would therefore be to intrude in the conversation that is the life of the Kingdom... the whole of the church, with all its discourse, is anticipation of our inclusion in that same conversation" (ST2:269). So from his Trinitarian understanding of God and the communion-ecclesiology understanding of the church he can conclude that to invoke the saints "no other miracle is required than the miracle of the church's existence" (ST2:269).

\section{CONCLUSIONS}

It is clear how Jenson, from the few examples mentioned here, attempt to open up new possibilities in the ecumenical debate with his proposals. What is also clear is the fact that his proposals are consistent with, and a result of, his whole Trinitarian theology. In a way his

20 Jenson adds that there is one question though and that is if the saints are aware and interested in us. His answer is that "in the Kingdom we will know one another by participation in God's own knowledge of us. If the saints know us at all, they know us infinitely better than we know ourselves; surely this makes them attractive - and fearsome - as intercessors" (ST2:269). 
proposals are a continuation of one of his main ecumenical works, Unbaptized God, because he consistently works towards a theology without the concept of a timeless God. This age-old misunderstanding of God's timelessness, and eventually impassibility, is according to Jenson a result of the metaphysical speculation of the West under the influence of Greek philosophy. ${ }^{21}$ Jenson proposes a much stronger narrative view of $\operatorname{God}^{22}$ which is according to him much more biblical and helps us to understand God as a timeful and a present God (as in the Eucharist). ${ }^{23}$ It is within this context that Jenson makes his, in my view, very helpful ecumenical proposals. ${ }^{24}$ Jenson's proposals need therefore to get the attention it is due and should be considered seriously by the church. Of specific importance is how his whole Trinitarian theology underlies these proposals and the whole coherence found throughout it, ${ }^{25}$ but that does not say that his theology and ecumenical proposals are without any problems.

A common point of critique is Jenson's location of Jesus' presence in our world. In his article, Trinity, Time, and Sacrament: Christ's Eucharist Presence in the Theology of Robert W. Jenson (2005), Jason Curtis convincingly shows that Jenson's "Trinitarian ontology, combined with more explicit language of bodily presence lends itself strongly to a biological presence..." (Curtis 2005:34) and "by pressing toward this temporal arrangement, Jenson implies a biological presence, despite a desire to avoid such a conclusion" (Curtis 2005:35). Curtis adds: "Jenson's Trinitarian ontology and his view of the Eucharist when pressed toward its logical end could unintentionally exclude the ascended, coming-again body, and in doing so may fail to grant his humanity its proper place" (2005:38). This problem links to the question of Jesus physical presence and his whole identification with the church and with the signs of the Eucharist. In Jenson's scheme the question of the Eucharist always revolves around where Jesus is temporally located and thus emphasizing the transformation of the elements. On the other hand Jesus identification with the church, as the totus Christus, is also problematic and lan McFarland, in his article The Body of Christ: Rethinking a Classic Ecclesiological Model (2005), indicates how Jenson's stress on Christ's objective presence in the world risks collapsing Christ into the church. ${ }^{26}$

21 Jenson says that in Unbaptized God he proposed that there was not a 'basic difference' between Catholicism and Reformation, but that "the problems stemmed from a 'basic agreement' in an inadequately Trinitarian intuition of God" (Jenson 2007:52).

22 This is a continuing theme for Jenson. See for example his: book Story and Promise: A Brief Theology of the Gospel about Jesus (1973. Philadelphia: Fortress Press), and his later article: "Can we have a story?" (2000. First Things 101:16-17). See also "How is Robert Jenson telling the Story?" (Verhoef, AH 2008. Scriptura, 2:231-243).

23 Curtis says for example: "Jenson's doctrine of Eucharist is directly dependent upon Trinity, who envelopes time - our time" (2005:35).

24 A lot more proposals have been made than the few discussed here. Jenson also contributed important ecumenical work about the historic episcopacy, the office of the pope, the justification by faith and on liturgical matters. Although they were not discussed here, the same coherence in his Trinitarian underlies his proposals in this regard (and therefore also the same critique on his theology is relevant).

25 Paul Carey (1999:133) says in this regard: "Jenson traces the problems which structure (and fracture) today's ecumenical theology to this most decisive conversation of the Christian tradition. The religious understanding of ancient Mediterranean Gentiles became an articulate theology in the writings of Greek philosophers, whose concept of the divine as timeless eternity was the most powerful rival to Jewish and Christian conceptions of God as historical redeemer. In locus after locus, Jenson's solutions to the problems of ecumenical theology involve uncovering an undigested nugget of philosophical timelessness (often operating as a hidden assumption common to both sides in a theological dispute) and suggesting ways to complete the evangelization the fathers started."

26 It is in the same line of thought that Pannenberg, Hart, Cumin, Burgess and Grenz criticises Jenson. Grenz formulates it strongly and says: "If I were to name what for me is the low point in the opening installment of the two volume set, it would have to be his equating of the resurrected body of Christ with 
This has of course implications for Jenson's whole understanding of the church as communionecclesiology. None the less Jenson does in my view succeed to find some new middle ground for ecumenical disputes by rethinking the identification of the church with the body of Christ. An understanding of God that is according to the Bible not a timeless God, allows Jenson to explore these new (and often unorthodox) theological and ecumenical possibilities.

Positive critique on Jenson's Trinitarian theology and on his ecumenical proposals includes that Jenson manages not to be biased towards his own denomination. Jenson has, for example, been accused of being too Catholic and being too Reformed from both sides. ${ }^{27}$ He says, for example, about his own Lutheran background that "it is really only for the sake of the Lutheran Christology that I continue to describe myself as a theological Lutheran" (Jenson 1992:23). It would be therefore wrong to describe Jenson's theology as denominational and a better description would be (like he himself said) to say that his theology is worked out for the one church of the future. ${ }^{28}$ Philip Cary (1999:133) wrote very appreciative of Jenson's aim in this regard: "Arguably the most beautiful and important theology of our time is being develop between the various churches, in ecumenical discussions which elucidate the structure of thought and practice common to all the particular Christian traditions. Robert Jenson's recent work is situated in that between, inhabiting the common space of ecumenical theology and examining its problems. The solutions he proposes are bold and innovative, often idiosyncratic and unlikely to be widely accepted - yet instructive and immensely suggestive to anyone who thinks theology should solve its problems not by conforming to the agendas set by the world (modernity, post modernity, or any other age) but by renewing its attention to the Gospel of Christ." It is an ecumenical future which we should keep on praying and working for, as the current Pope (Benedict XVI when he was still Cardinal Joseph Ratzinger) said: "further major ecumenical progress depends on a new 'depth of faith' worked by a new initiative of the Spirit. That can happen at any time and is what we should pray for..." (Jenson 2006:33). Jenson's Trinitarian and ecumenical theology is indeed a prayer for that.

\section{BIBLIOGRAPHY}

Braaten, CE \& Jenson, RW (eds) 1996. The Catholicity of the Reformation. Grand Rapids: Eerdmans.

Braaten, CE 2000. Robert Williams Jenson - A Personal Memoir. In: Gunton, CE (ed) 2000. Trinity, Time, and Church. A Response to the Theology of Robert W. Jenson. 1-9. Grand Rapids: Eerdmans.

Braaten, CE \& Jenson, RW (eds) 2003. In One Body through the Cross. The Princeton Proposal for Christian Unity. Grand Rapids: Eerdmans.

Braaten, CE \& Jenson, RW (eds) 2003. Jews and Christians. People of God. Grand Rapids: Eerdmans.

the church" (2003:214). It can however be said in defence of Jenson that he does not explicitly choose for one of these options and his formulations are mostly open ended on these issues (and some may think contradictory as well).

27 Mattes (2000:485-486) says: "Jenson has attempted to develop not a Lutheran but an ecumenical theology particularly faithful to the catholic and orthodox traditions. Evangelical Lutherans will probably be apt quickly to note just how "Catholic" Jenson is: he argues for a pope, a historic episcopate, the Eucharist primarily as sacrifice, salvation as deification and other such matters. However, it is highly likely that Roman Catholic and Orthodox readers will, by contrast, find Jenson to be 'all too Lutheran.' Abraham, our example of a person of faith for Jenson, lives by faith and nothing else. Christian growth in charity is nothing other than a daily turning to baptism... Lutheran themes, then, are pivotal though not definitive in his construction of an ecumenical theology."

28 Jenson said: “... it is a great blessing specifically to theology that we need not wait for the church to be undivided to do theology for and even of the undivided church. For theology is itself a form of the waiting we must practice. The present work [his Systematic Theology] is deliberately done in such anticipation of the one church, and this will be throughout apparent, in its use of authorities and its modes of argument" (ST1:viii). 
Braaten, CE \& Jenson, RW (eds) 2004. The Ecumenical Future. Grand Rapids: Eerdmans.

Carey, P 1999. Book reviews. Scottish Journal of Theology 52:1, 133-135.

Curtis, JM 2005. Trinity, Time, and Sacrament: Christ's Eucharistic Presence in the Theology of Robert W. Jenson. Journal for Christian Theological Research no 10, 21-38.

Grenz, SJ 2003. The Divine Fugue: Robert Jenson's Renewed Trinitarianism. Perspectives in Religious Studies 30 no 2, 211-216.

Gunton, CE (ed) 2000. Trinity, Time, and Church. A Response to the Theology of Robert Jenson. Grand Rapids: WB Eerdmans.

Jenson, RW 1973. Story and Promise: A Brief Theology of the Gospel about Jesus. Philadelphia: Fortress Press.

Jenson, RW 1978. Visible Words: The Interpretation and Practice of the Christian Sacraments. Philadelphia: Fortress Press.

Jenson, RW 1992. Unbaptized God: The basic flaw in Ecumenical Theology. Minneapolis: Fortress Press. Jenson, RW 1996. The Church as Communio, In: Braaten, CE \& Jenson, RW (eds) The Catholicity of the Reformation. Grand Rapids: Eerdmans.

Jenson, RW 1997. Systematic Theology, Volume 1: The Triune God. Oxford: Oxford University Press. Jenson, RW 1999. Systematic Theology, Volume 2: The Works of God. Oxford: Oxford University Press. Jenson, RW 2000. Can we have a story?. First Things 101:16-17.

Jenson, RW 2006. God's time, our time. Christian Century May 2, 31-35.

Jenson, RW 2007. A Theological Autobiography, to Date. Dialog 46:1, 46-54.

Mattes, MC 2000. An Analysis and Assessment of Robert Jenson's Systematic Theology. Lutheran Quarterly 14:4, 463-494.

McFarland, IA 2005. The Body of Christ: Rethinking a Classic Ecclesiological Model. International Journal of Systematic Theology 7:3, 225-245.

Verhoef, AH 2008. How is Robert Jenson telling the Story? Scriptura, 2:231-243.

\section{KEY WORDS}

Robert Jenson

Trinity

Time

Ecumenism

Eucharist

\section{TREFWOORDE}

Robert Jenson

Triniteit

Tyd

Ekumene

Eucharistie 